35. Shaw, K. N. F., Lieberman, E., Koch, R., and Donnell, G. N.: Cystathioninuria. Amer. J. Dis. Child., I13: 119 (1967).

36. Snell, E. E., Fasella, P. M., Braunstein, A., and Rossi Fanelli, A.: Chemical and Biological Aspects of Pyridoxal Catalysis, pp. 1-11 (Macmillan Co., New York, 1963).

37. Stanbury, J. B., Wyngaarden, J. B., and Fredrickson, D. S.: The Metabolic Basis of Disease, Ed. 3, p. 10 (McGraw-Hill, New York, 1972).

38. Steinmann, B., and Niederwieser, A.: Manuscript in preparation.

39. Sturman, J. A., Gaull, G. E., and Räihä, N. C. R.: Absence of cystathionase in human fetal liver: Is cystine essential? Science, 169: 74 (1970).

40. Sturman, J. A., and Kremzner, L. T.: Polyamine biosynthesis and vitamin $\mathbf{B}_{6}$ deficiency. Evidence for pyridoxal phosphate as coenzyme for $S$-adenosylmethionine decarboxylase. Biochim. Biophys. Acta, 372: 162 (1974).

41. Tada, K., Yoshida, T., Yokoyama, Y., Sato, T., Nakagawa, H., and Arakawa, T.: Cystathioninuria not associated with vitamin $B_{6}$ dependency: A probably new type of cystathioninuria. Tohoku J. Exp. Med., 95: 235 (1968).

42. Tallan, H. H., Pascal., T. A., Schneidman, K., Gillam, B. M., and Gaull, G. E.: Homolanthionine synthesis by human liver cystathionase. Biochem. Biophys. Res. Commun., 43: 303 (1971).
43. Tedesco, T. A., and Mellman, W. J.: Galactosemia: Evidence for a structural gene mutation. Science, 172: 727 (1971).

44. Uriel, J.: Characterization of enzymes in specific immune-precipitates. Ann. N. Y. Acad. Sci., 103: 956 (1963).

45. We thank Drs. C. Parker, Y. Wada, B. Steinmann and R. Gitzelmann for providing blood for culture of lymphoid cell lines from patients with primary cystathioninuria. We also thank Dr. J. Sturman for performing the $S$-adenosylmethionine decarboxylase assays and Dr. M. Kehoe and Mr. D. Pascal for helpful discussion and advice.

46. These studies were performed with the informed consent of the subjects or, in the case of children, with the informed consent of their parents.

47. This work was published in part (Science, 190: 1209 (1975)).

48. This research was supported by the New York State Department of Mental Hygiene, the Lalor Foundation, National Institutes of Health Genetics Center Grant GM-19443.

49. Requests for reprints should be addressed to: Theresa A. Pascal, Institute for Basic Research in Mental Retardation, 1050 Forest Hill Road, Staten Island, NY 10314 (USA).

50. Received for publication March 7, 1977.

51. Accepted for publication May 25, 1977.
Autoxidation Bohr effect 2,3-diphosphoglycerate heme-heme interaction hemoglobin, fetal and adult methemoglobin

$P_{50}$

\title{
Oxygen Affinity of Hemoglobins F and A Partially Oxidized to Methemoglobin: Influence of 2,3-Diphosphoglycerate
}

\author{
H. T. VERSMOLD, ${ }^{(39)}$ K. FÜRST, K. BETKE, AND K. P. RIEGEL \\ Division of Neonatology, Kinderklinik der Universität, Munich, Federal Republic of Germany
}

\section{Summary}

Oxygen equilibrium curves of partially autoxidized adult (HbA) and fetal hemoglobins (HbF) were determined at 275\% methemoglobin (met-Hb). Hemoglobin concentration of 5 $\mathrm{mM}$, pH 7.15 (Tris $0.05 \mathrm{M}$ ), and temperature of $37^{\circ}$ corresponded to intraerythrocytic in vivo conditions. With increasing met-Hb fractions the curves became shifted to the left and approached a hyperbolic form: $P_{50}$ of both $\mathrm{HbA}$ and $\mathrm{HbF}$ decreased in absence of 2,3-diphosphoglycerate (2,3-DPG) from about 13 to 7 Torr, and Hill's $n$ from 2.7 to 1.25 . Independent of the met-Hb fraction the alkaline Bohr effect was increased by 2,3-DPG. The allosteric effect of 2,3-DPG on $P_{50}$ decreased with increasing met-Hb. At all oxidation levels this effect was smaller on $\mathrm{HbF}$ than on $\mathrm{HbA}$ : At $50 \%$ met-Hb $P_{50}$ of $\mathrm{HbF}$ is increased by 0.7 Torr $/ \mathrm{mM}$ 2,3-DPG increase, $P_{50}$ of $\mathrm{HbA}$ by $1.3 \mathrm{Torr}$, respectively. There was no evidence of preferential autoxidation of $\alpha$ or non- $\alpha$ chains of the hemoglobin molecule.

Oxidized hemoglobin does not take part in oxygen transport. In addition a left-shifted, more hyperbolic curve means restricted oxygen unloading from the remaining active hemoglobin. Thus, from application of our results to clinical conditions it must be concluded that sustained methemoglobinemia, despite partial compensation by 2,3-DPG, may interfere with oxygen supply to tissue, particularly in the perinatal period, when $\mathrm{HbF}$ prevails.

\section{Speculation}

Tissue oxygen supply, as calculated from the present data on $\mathrm{O}_{2}$ capacity, $\mathbf{P}_{50}, 2,3-\mathrm{DPG}$ reactivity, Hill's $n$, and Bohr factors, appears to be markedly lowered in methemoglobinemia, particularly in presence of fetal hemoglobin. Reduced tissue oxygen supply in the perinatal period, in addition to a generalized cytochrome $b_{5}$ reductase deficiency $(22)$, might contribute to irreversable cerebral dysfunction in hereditary methernoglobinemia.

It is well known that the oxygen affinity of partially oxidized $\mathrm{HbA}$ is increased $(8,10)$. However, this pronounced left shift of the hemoglobin oxygen equilibrium curve with increasing fractions of met- $\mathrm{Hb}$ in vitro was not observed in patients with sustained methemoglobinemia (for references see the reviews of Jaffé and Hsieh (14) and Kiese (17)). This discrepancy could have a methodologic cause. The in vitro experiments were performed on highly diluted solutions in presence of $0.6 \mathrm{M}$ inorganic phosphate. Both dilution (12) and inorganic phosphate (5) affect hemoglobin oxygen affinity. Moreover, the role of organic phosphates, mainly 2,3-DPG, as important allosteric effectors of hemoglobin, was not taken in account at that time.

More recently partially oxidized hemoglobins have attracted new attention. For instance, the question arose of whether the altered hemoglobin oxygen affinity could be responsible for the 
occasionally observed brain damage in hereditary methemoglobinemia (see review, Jaffé and Hsieh (14)). On the other hand, partially oxidized hemoglobins, particularly artificial mixed valency hybrids, served as experimental tools to study the properties of individual subunits within the tetrameric framework of the hemoglobin molecule.

The present study on concentrated hemoglobin solutions was performed to define the influence of 2,3-DPG on the oxygen affinity of partially oxidized solutions of fetal and adult hemoglobin. Red cell 2,3-DPG is known to increase in response to hypoxemia (see review (35)), and this also in methemoglobinemia $(21,32)$. The allosteric effect of $2,3-\mathrm{DPG}$ is known to be smaller on $\mathrm{HbF}$ than on $\mathrm{HbA}(4,6,31)$, but the interaction of 2,3-DPG with partially autoxidized $\mathrm{HbF}$ has not yet been studied. Thus, data obtained under physiologic conditions (1) should provide estimations on the oxygen supply of tissues in newborn and older infants with methemoglobinemia; (2) might yield an information about the in vivo relevance of a nonequivalence of chains in hemoglobin oxidation.

\section{PROCEDURES AND METHODS}

Human adult and fetal hemoglobins were isolated from adult blood (with informed consent) and placental cord blood according to the method of Jonxis and Huisman (15) by DEAESephadex A-50 chromatography (Tris $0.05 \mathrm{M}$ ). $\mathrm{HbA}_{2}$, eluted at $\mathrm{pH} 8.1$, was discarded. $\mathrm{HbA}$ was eluted at $\mathrm{pH} 7.8$. The remaining fetal hemoglobin $\left(\mathrm{HbF}_{0}\right.$ and $\left.\mathrm{HbF}_{1}\right)$ was washed from the resin at $\mathrm{pH} 6.5$. The isolated $\mathrm{HbA}$ and $\mathrm{HbF}$ were reconcentrated to $30 \mathrm{~g} / 100 \mathrm{ml}$ in $0.05 \mathrm{M}$ Tris, $\mathrm{pH} 7.15$, by ultrafiltration using an Amicon (Oosterhout, Holland) membrane XM 50. The final 2,3-DPG concentration was $<10^{-5} \mathrm{M}$. To prevent met-Hb formation resin, buffers and hemoglobin solutions were equilibrated with oxygen throughout the procedure; temperature during chromatography did not exceed $10^{\circ}$, during ultrafiltration $4^{\circ} ; \mathrm{pH}$ was kept above 7.5 until the final dialysis against $0.05 \mathrm{M}$ Tris, $\mathrm{pH} 7.15$.

Hemoglobins were autoxidized by keeping them aerobically at $37^{\circ}$ and $\mathrm{pH} 7.15$ until the desired level of met-Hb was reached. It took approximately $50 \mathrm{hr}$ to reach $75 \%$ met- $\mathrm{Hb}$. In random samples no bacterial contamination was found, and single control experiments in presence of $1 \mu \mathrm{g} / \mathrm{ml}$ gentamycin gave normal results. Gentamycin did not influence the rate of autoxidation.

After autoxidation 2,3-DPG was added to final concentrations of $1 \mathrm{mM}$ and $5 \mathrm{mM}$ to two of three aliquots. 2,3-DPG (Boehringer, Mannheim) had been freed of cyclohexyl ammonium ions by cation exchange chromatography (Dowex $50 \mathrm{~W}$ $\mathrm{X} 8,200-400$ mesh, $\mathrm{H}^{+}$form), and titrated to $\mathrm{pH} 7.15$ by $\mathrm{NaOH}$.

The three specimens, containing either no 2,3-DPG, $1 \mathrm{mM}$ 2,3-DPG, or $5 \mathrm{mM} \mathrm{2,3-DPG} \mathrm{respectively,} \mathrm{were} \mathrm{equilibrated}$ simultaneously in Laué tonometers at $37^{\circ}$ with water vaporsaturated gas mixtures of known composition $\left(\mathrm{O}_{2}\right.$ in $\left.\mathrm{N}_{2}\right)$. Oxygen content and oxygen capacity (hemoglobins equilibrated with $40 \% \mathrm{O}_{2}$ ) were measured in triplicate in $0.03(0.02)$-ml samples with a GCM 4 (Beckman Instruments, Munich) gas chromatograph combined with a Natelson microgasometer 600 (Scientific Industries, Springfield, MA) or a Lex- ${ }_{2}$-Con oxygen analyzer (Lexington Instruments Corp., Waltham, MA). Both methods yielded results in perfect agreement $\left(\mathrm{Lex}-\mathrm{O}_{2}-\mathrm{Con}\left(\mathrm{ml} \mathrm{O}_{2} / 100\right.\right.$ $\mathrm{ml})=1.0247 \mathrm{GCM}\left(\mathrm{ml} \mathrm{O}_{2} / 100 \mathrm{ml}\right)-0.313 ; \mathrm{s}_{\mathbf{y} . \mathrm{x}}=0.453 ; r=$ 0.999 ; range $3-46 \mathrm{ml} \mathrm{O} / 100 \mathrm{ml} ; n=55$ ). $\mathrm{O}_{2}$ tension and $\mathrm{pH}$ were determined by an IL pH/gas analyzer $113 \mathrm{~S} 1$ (Instrumentation Laboratories, Boston, MA). Oxygen hemoglobin equilibrium curves were constructed graphically according to the method of Bartels and Harms (1). Their position is expressed by $\log \mathrm{P}_{50}$ at $\mathrm{pH} 7.15$ using Bohr factors $\left(\Delta \log \mathrm{PO}_{2} / \Delta \mathrm{pH}\right)-0.39$ for 2,3-DPG-free hemoglobin solutions, -0.43 at $1 \mathrm{mM} \mathrm{2,3-}$ DPG, and -0.56 at $5 \mathrm{mM} 2,3-\mathrm{DPG}$. These factors had been derived from experiments on specimens buffered with Tris 0.05
$\mathrm{M}, \mathrm{pH} 7.1$ and 7.4 , at $50 \% \mathrm{O}_{2}$ saturation and were found not significantly influenced by met-Hb (in accordance with the data of Enoki et al. (10)) or the hemoglobin type. These data agree well with those of Bauer (2). Met- $\mathrm{Hb}$ was determined in duplicate spectrophotometrically according to the method of Evelyn and Malloy (11). Independently it was calculated from the "active" to total hemoglobin ratio. The active hemoglobin concentration was derived from the oxygen capacity divided by the Hüfner factor, which was $1.38 \pm 0.02$ (milliliters per $\mathrm{g}$ ) in adult and cord blood hemoglobin.

One preparation of $\mathrm{HbA}(5 \mathrm{mM}$; $\mathrm{pH} 7.15)$ has been autoxidized to about $50 \%$ met-Hb at $37^{\circ}$ under three different conditions: (I) aerobically, (II) at a $\mathrm{pO}_{2}$ of about 10 Torr, and (III) aerobically in presence of $5 \mathrm{mM} 2,3$-DPG. The oxidized samples I and II were then examined in absence of 2,3-DPG and after addition of $5 \mathrm{mM} 2,3-\mathrm{DPG}$, as compared to sample III which already contained $5 \mathrm{mM} 2,3-\mathrm{DPG}$.

The effect of $0.6 \mathrm{M}$ inorganic phosphate $\mathrm{pH} 7.15$ on $\mathrm{P}_{50}$ of HbA $(n=14)$ and $\mathrm{HbF}(n=16)$ was determined by the same procedure at low and high met-Hb fractions. For these experiments an ultrafiltration of the isolated $\mathrm{HbA}$ and $\mathrm{HbF}$ against the phosphate buffer was performed before concentration of the hemoglobins.

\section{RESULTS}

\section{OXYGEN AFFINITY}

The effects of met-Hb and 2,3-DPG on $\mathrm{P}_{50}$ of $\mathrm{HbA}$ and $\mathrm{HbF}$ at physiologic red cell hemoglobin concentration of $5 \mathrm{mM}, \mathrm{pH}$ 7.15 , and $37^{\circ}$ are illustrated in Figure 1 as semilogarithmic plots.

$P_{50}$ of the "stripped" (2,3-DPG-free) HbA in absence of met$\mathrm{Hb}$ is approximately $12.5 \mathrm{Torr}$, at $50 \%$ met-Hb 10 Torr, and at $75 \%$ met-Hb only 7.5 Torr. When 2,3-DPG is added, the corresponding $\mathrm{P}_{50}$ values are $15.0,11.7$, and 8.5 Torr at $1 \mathrm{mM}$

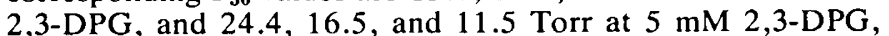
respectively. It can be seen that: $(1)$ hemoglobin autoxidation reduces $\mathrm{P}_{50}$; this reduction is enhanced above $50 \%$ met- $\mathrm{Hb}$, thus linear regressions relating $\log \mathrm{P}_{50}$ to met- $\mathrm{Hb}$ are flatter at $2-50 \%$ met- $\mathrm{Hb}$ than above $50 \%$ met-Hb (see Table 1 and Fig. 1 ) and that (2) increasing autoxidation of $\mathrm{HbA}$ reduces the allosteric effect of 2,3-DPG. In absence of met-Hb there is a $\Delta \mathrm{P}_{50} / \Delta 2,3-\mathrm{DPG}$ ratio of $2.4 \mathrm{Torr} / \mathrm{mM}$, at $50 \%$ met- $\mathrm{Hb}$ of 1.3 Torr $/ \mathrm{mM}$, and at $75 \%$ met- $\mathrm{Hb}$ of $0.9 \mathrm{Torr} / \mathrm{mM}$.

Compared to these results changes observed with $\mathrm{HbF}$ are as follows: (1) $\mathrm{P}_{50}$ of "stripped" $\mathrm{HbF}$ is not significantly different from that of $\mathrm{HbA}$; in the absence of met- $\mathrm{Hb} \mathrm{P}_{50}$ averages 13.2 Torr, at $50 \%$ met-Hb 9.8 Torr, and at $75 \%$ met-Hb 6.5 Torr. There are also different slopes below and above $50 \%$ met-Hb (Table 1). (2) The allosteric effect of 2,3-DPG on $\mathrm{HbF}$ is smaller than on $\mathrm{HbA}$. The $\Delta \mathrm{P}_{50} / \Delta 2,3-\mathrm{DPG}$ ratio in $\mathrm{HbF}$ is similarly affected by autoxidation than in $\mathrm{HbA}$ : At low met-Hb levels this ratio is approximately 1.1 , at $50 \%$ met- $\mathrm{Hb} 0.7$, and $75 \%$ met-Hb $0.5 \mathrm{Torr} / \mathrm{mM}$. These figures are 45,54 , and $56 \%$ of the respective $\mathrm{HbA}$ values.

Table 2 shows the results of $\mathrm{HbA}$ autoxidation to about 50 percent met-Hb at (I) $\mathrm{pO}_{2} 140$ Torr (Control), (II) $\mathrm{pO}_{2}$ about 10 Torr, and (III) if autoxidation occurred in presence of $5 \mathrm{mM}$ 2,3-DPG at $\mathrm{pO}_{2} 140$ Torr. No differences were observed in this series with regard to $\mathrm{P}_{50}$ and $\Delta \mathrm{P}_{50} / \Delta 2,3-\mathrm{DPG}$ when oxidation had occurred at low $\mathrm{pO}_{2}$, a condition which should enhance $\alpha$ chain autoxidation. Furthermore, no differences in $P_{50}$ were found when autoxidation had occurred in presence of 2,3-DPG, a condition which should enhance $\beta$ chain autoxidation, as compared to autoxidation and subsequent addition of 2,3-DPG.

Oxygen affinity of $\mathrm{HbA}$ or $\mathrm{HbF}$ in $0.6 \mathrm{M}$ phosphate buffer $\mathrm{pH} 7.15$ was on the order of that found in $0.05 \mathrm{M}$ Tris in the presence of $1 \mathrm{mM} 2,3-\mathrm{DPG}$. At $9 \%$ met- $\mathrm{Hb}(8.7 \pm 1.0 \% ; n=$ $8)$, mean $\mathrm{P}_{50}$ of $\mathrm{HbA}$ was $14.5( \pm 0.8) \mathrm{Torr}$, and at $68 \%(67.7$ $\pm 1.5 \% ; n=6) 9.9( \pm 0.4)$ Torr. Corresponding values of $\mathrm{HbF}$ 


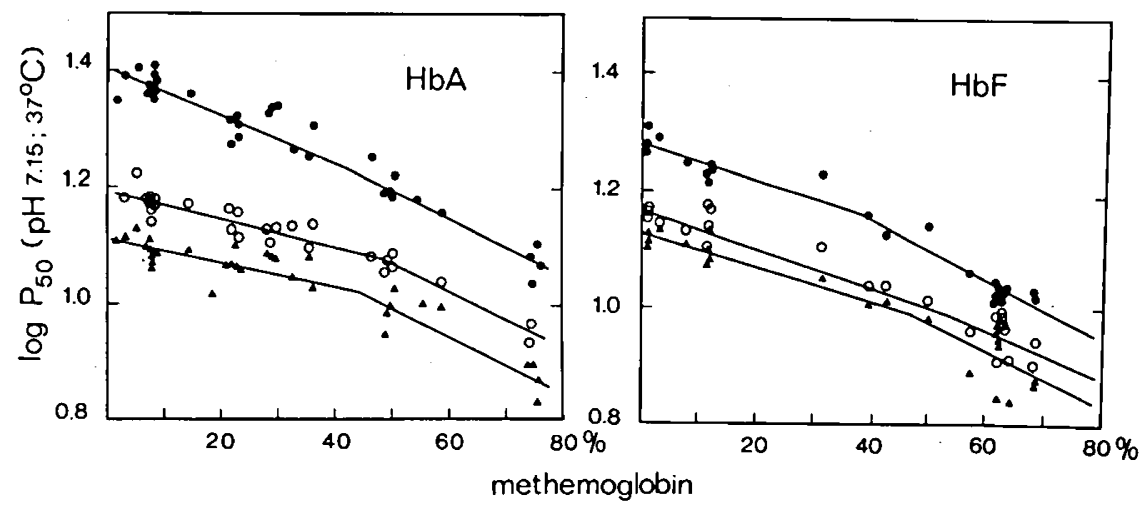

Fig. 1. Dependence of $\log \mathrm{P}_{30}\left(\mathrm{pH} 7.15 ; 37^{\circ}\right)$ of partially autoxidized $\mathrm{HbA}$ and $\mathrm{HbF}$ on the percentage of met-Hb in absence of 2,3-DPG $\left(<10^{-5} \mathrm{M}\right)(\boldsymbol{\Delta})$ and in presence of $1 \mathrm{mM}(\mathrm{O})$ and $5 \mathrm{mM} \mathrm{2,3-DPG}(\bullet)$. Regression lines were calculated for data below $50 \%$ met-Hb and above $50 \%$ met- $\mathrm{Hb}$ (see regression constants in Table 1). Hemoglobin concentration $5 \mathrm{mM}$ (tetramer) in Tris $0.05 \mathrm{M}$, $\mathrm{pH} 7.15$, corresponding to in vivo conditions.

Table 1. Oxygen affinity of $H b A$ and $H b F$ during autoxidation ${ }^{1}$

\begin{tabular}{|c|c|c|c|c|c|c|c|c|}
\hline Hb type & $\begin{array}{c}\text { met-Hb range, } \\
\% \\
\end{array}$ & $\begin{array}{c}\text { 2,3-DPG, } \\
\mathrm{mM}\end{array}$ & $n$ & $\begin{array}{l}b_{y} \cdot \mathbf{x} \\
\times 100\end{array}$ & $\mathbf{a}$ & $r$ & $s_{y} \cdot x$ & $\begin{array}{c}2 P \\
(b \neq b)\end{array}$ \\
\hline \multirow[t]{6}{*}{ A } & $0-55$ & 0 & 27 & -0.2045 & 1.1140 & -0.813 & $0.0248=$ & \\
\hline & & 1 & 26 & -0.2361 & 1.1925 & -0.889 & $0.0200 \neg$ & $-<0.001$ \\
\hline & & 5 & 30 & -0.4017 & 1.4058 & -0.921 & 0.0296 & \\
\hline & $40-80$ & 0 & 10 & -0.4690 & 1.2334 & -0.879 & 0.0330 & $<0.01$ \\
\hline & & 1 & 8 & -0.4668 & 1.3047 & -0.967 & 0.0154 & \\
\hline & & 5 & 12 & -0.4700 & 1.4293 & -0.896 & 0.0303 & \\
\hline \multirow[t]{6}{*}{$\mathbf{F}$} & $0-55$ & 0 & 13 & -0.2747 & 1.1286 & -0.944 & 0.0176 & \\
\hline & & 1 & 13 & -0.2863 & 1.1712 & -0.922 & 0.0221 & \\
\hline & & 5 & 13 & -0.2961 & 1.2825 & -0.920 & $0.0232 \neg$ & \\
\hline & $40-80$ & 0 & 13 & -0.4935 & 1.2313 & -0.597 & 0.0497 & $-<0.05$ \\
\hline & & 1 & 13 & -0.4345 & 1.2336 & -0.729 & 0.0305 & \\
\hline & & 5 & 12 & -0.5065 & 1.3595 & -0.902 & $0.0190 \sqsupset$ & \\
\hline
\end{tabular}

${ }^{1}$ Regression constants of the correlation $\log \mathrm{P}_{30}$ (Torr) vs. methemoglobin (percent) in presence of different concentrations of $2,3-\mathrm{DPG}$ at $37^{\circ}$, $\mathrm{pH} 7.15 ; \log \mathrm{P}_{30}$ (Torr) $=\mathrm{b} \times$ met-Hb (percent) $+\mathrm{a}$.

Table 2. $P_{50}$ and 2,3-DPG reactivity of $\mathrm{HbA}$ after autoxidation at low $\mathrm{O}_{2}$ tension and in presence of 2,3-DPG

\begin{tabular}{|c|c|c|c|c|c|c|c|c|}
\hline \multicolumn{4}{|c|}{ Conditions during autoxidation ${ }^{1}$} & \multicolumn{3}{|c|}{ Conditions at examination } & \multicolumn{2}{|c|}{ Results } \\
\hline Sample & $\begin{array}{l}\mathrm{pO}_{2}, \\
\text { Torr }\end{array}$ & $\begin{array}{c}\text { 2,3-DPG } \\
\mathrm{mM}\end{array}$ & $\mathrm{pH}$ & Sample & $\begin{array}{c}\text { met-Hb } \\
\%\end{array}$ & $\begin{array}{c}2,3-\mathrm{DPG} \\
\mathrm{mM}\end{array}$ & $\begin{array}{c}P_{50} \\
\left(\mathrm{pH} \mathrm{7.15;37^{ \circ }}\right), \\
\text { Torr }\end{array}$ & $\begin{array}{c}P_{50}(D P G) / \\
P_{50} \text { (no DPG) }\end{array}$ \\
\hline \multirow[t]{2}{*}{ I } & 140 & 0 & 7.15 & Ia & 55.0 & 0 & 8.0 & $1.89(\mathrm{Ib} / \mathrm{Ia})$ \\
\hline & & & & $\mathrm{Ib}$ & 55.0 & 5 & 15.1 & \\
\hline III & 140 & 5 & 7.14 & III & 46.3 & 5 & 15.5 & $1.94(\mathrm{II} / \mathrm{Ia})$ \\
\hline
\end{tabular}

${ }^{1}$ Further conditions as given in the text.

$(n=8)$ were $15.0 \pm 0.5$ Torr (at $10.8 \pm 3.5 \%$ met $-\mathrm{Hb})$ and $9.6 \pm 0.4$ Torr (at $64.8 \pm 3.3 \%$ met- $\mathrm{Hb}$ ).

\section{HEME-HEME-INTERACTION}

Besides the left shift of the hemoglobin oxygen equilibrium curve with increasing hemoglobin oxidation a transformation of the curve to a less sigmoid shape occurs $(8,10,24)$. As is shown in Figure 2, changes of Hill's $n$ with autoxidation in $\mathrm{HbA}$ and $\mathrm{HbF}$ are not significantly different. In unoxidized samples Hill's $n$ is approximately 2.7 , at $50 \%$ met-Hb 1.5 , and at $75 \%$ met-Hb 1.25. Our methods were not sensitive enough to detect differences between 2,3-DPG-free and 2,3-DPG-substituted hemoglobin solutions with regard to cooperativity.

\section{DISCUSSION}

The results obtained on 2,3-DPG-free $\mathrm{HbF}$ are not significantly different from those on HbA. Upon autoxidation hemoglobin oxygen affinity increases and the heme-heme interaction decreases, both in a nonlinear fashion. $P_{50}$ differences between $\mathrm{HbA}$ and $\mathrm{HbF}$ were seen in presence of 2,3-DPG. At all oxidation levels the allosteric effect of 2,3-DPG on $\mathrm{HbF}$ was smaller than that on HbA. The effect of 2,3-DPG on $P_{50}$ of 


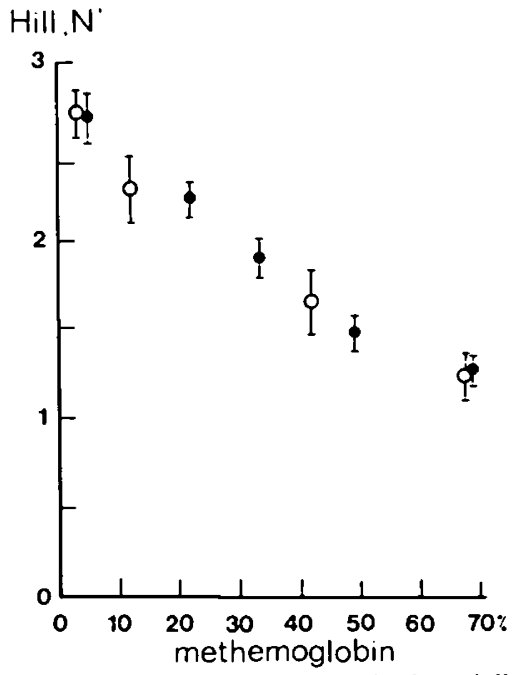

Fig. 2. Dependence of cooperativity (Hill's $n$ ) of partially autoxidized $\mathrm{HbA}(\bullet)$ and $\mathrm{HbF}(\mathrm{O})$ on the percentage of met-Hb. Conditions as in Figure 1.

$\mathrm{HbA}$ and of $\mathrm{HbF}$ decreased with increasing met-Hb. These findings shall be discussed with respect to a nonequivalence of chains in the hemoglobin tetramer and to the implications on oxygen transport.

\section{STRUCTURE-FUNCTION RELATIONS IN HEMOGLOBIN OXIDATION}

The functional properties of partially oxidized hemoglobins and their response to allosteric effectors should reflect the relation between structure and function of the hemoglobin molecule. Partially oxidized hemoglobin is a mixture of hemoglobin molecules oxidized to different degrees (13) with different functional properties (20). Fully oxidized molecules do not participate in reversible oxygen binding. At least one unoxidized heme is needed to react with oxygen, and at least two for cooperative binding of oxygen and 2,3-DPG.

In half-oxidized hemoglobins dissociation of ligand from the ferrous subunits causes a change from the quarternary oxy- or $\mathrm{R}$ structure to the deoxy- or $\mathrm{T}$ structure. That change, favored by 2,3-DPG, causes the tertiary $r$ structure of the ferric subunits to alter (28-30). This concept would provide an explanation for the well preserved effect of 2,3-DPG on $P_{50}$ of our partially autoxidized hemoglobins, irrespective of a functional heterogeneity of chains.

The functional properties of half-oxidized hemoglobins and their reactivity to 2,3-DPG depend, furthermore, on whether they exist mainly as $\alpha$-met hybrids $\left(\alpha^{+}{ }_{2} \beta_{2}\right)$ or as $\beta$-met hybrids $\left(\alpha_{2} \beta^{+}\right)$. A functional heterogeneity of chains in hemoglobin oxidation has been observed on artificial mixed valency hybrids at low hemoglobin concentrations. Those hybrids with oxidized $\alpha$ chains show a more pronounced 2,3-DPG binding than do the hybrids with oxidized $\beta$ chains (3) at $5 \times 10^{-5} \mathrm{M} \mathrm{Hb}$ (tetramer). Furthermore the 2,3-DPG effect on $\mathrm{P}_{50}$ of the $\alpha$ met hybrid is stronger than on the $P_{50}$ of the $\beta$-met hybrid (24) at a hemoglobin concentration of $5 \times 10^{-5} \mathrm{M}$ (heme equivalents).

A preferential autoxidation of $\alpha$ chains of oxyhemoglobin A has been demonstrated by Mc Quarry and Gibson (23), Mansouri and Winterhalter $(25,26)$, and Edelstein and Gibson (9). It has to be stated, however, that our observations on concentrated partially autoxidized hemoglobins do not allow a definite evaluation as to whether $\alpha$ or non- $\alpha$ chains ( $\beta$ or $\gamma$ chains) are oxidized preferentially, because our data were obtained from a mixture of hemoglobin molecules oxidized to different degrees, and are therefore not directly comparable to pure mixed valency hybrids. Furthermore, under the conditions of our study, an exchange of hemes among hemoglobin molecules (7) will affect the distribution of oxidized hemes on $\alpha$ and non- $\alpha$ chains. Therefore, our functional data should not reflect the preferential autoxidation of any chain type, but rather a final state of equilibrium.

An enhancement of preferential $\alpha$ chain autoxidation has been described in presence of 2,3-DPG (26), or inositol hexaphosphate (9) while autoxidation at low $\mathrm{pO}_{2}$ is speeding up $\beta$ chain oxidation (26). We therefore compared the functional properties of $\mathrm{HbA}$ after partial autoxidation in presence of 2,3DPG to those after partial autoxidation at low $\mathrm{pO}_{2}$. Under these conditions, which should yield a relatively high fraction of oxidized $\alpha$ chains or $\beta$ chains, respectively, no functional differences have been observed (Table 2), probably because of the redistribution of oxidized hemes mentioned above. These data indicate that in vivo the $\mathrm{P}_{50}$ of partially autoxidized hemoglobins is close to the presented values even when autoxidation occurs under the most extreme variations of red cell conditions.

\section{OXYGEN TRANSPORT IN METHEMOGLOBINEMIA}

The following parameters impair oxygen unloading from blood to the tissues in methemoglobinemia: $(I)$ the diminished oxygen capacity, (2) the left shift of the oxygen equilibrium curve, and (3), to a certain extent, the reduced heme-heme interaction. In addition, otherwise reliable compensatory mechanisms must be considered insufficient. Cardiac output (other than in anemia) fails to respond substantially (27) to methemoglobinemia. Erythropoiesis, too, responds poorly to methemoglobinemia: the increase of total hemoglobin levels is smaller than in comparable arterial hypoxemia $(16,32)$.

Methemoglobin Distribution and Oxygen Affinity. A left shift of the blood oxygen dissociation curve in methemoglobinemia will occur only if met-Hb is not completely segregated on single red cells (27). In $\mathrm{NADH}$ met-Hb reductase deficiency an unequal distribution, although not an all-or-none distribution of met-Hb on red cells $(16,19)$ has been been demonstrated by the elution technique of Kleihauer and Betke (18), while the toxic methemoglobinemia met-Hb is more equally distributed (19). An unequal distribution of partially oxidized hemoglobin on red cells should result in a wide range of $P_{50}$ values among single red cells, with a tendency towards normal of the mean blood $\mathrm{P}_{50}(16)$.

2,3-DPG and Oxygen Affinity. According to the present data increased red cell 2,3-DPG concentrations as seen in methemoglobinemic patients $(21,32)$ are "correcting" the position of the left shifted blood oxygen equilibrium curve back towards normal. Indeed, in spite of $47 \%$ met-Hb in a 1 -year-old patient with NADH met-Hb reductase deficiency, we observed (32) an only moderately decreased blood $\mathrm{P}_{50}$ value of 24.8 Torr $(\mathrm{pH}$ $7.4,37^{\circ}$; normal children of comparable age $28.4 \pm 1.1(n=$ 11)), which was well explained by a 2,3-DPG level increased to $7.9 \mathrm{mM}$ (normal children $4.4 \pm 0.9(n=17)$ ). Different red cell 2,3-DPG concentrations and possibly an unequal distribution of met-Hb may explain the conflicting reports on decreased or even normal $P_{50}$ values in this disease.

These changes, however, do not outweigh the reduced $\mathrm{O}_{2}$ capacity; all $\mathrm{O}_{2}$ equilibrium curves determined as yet in hereditary methemoglobinemia - with a low or a "normal" $P_{50}$ - have in common a shift far to the left in comparison to reference curves of equally anemic subjects. The "correction" of $P_{50}$ in methemoglobinemia is less pronounced in the presence of $\mathrm{HbF}$, i.e., in early infancy.

2,3-DPG and Methemoglobin Formation. Excess 2,3-DPG may be a disadvantage in hereditary methemoglobinemia: there is evidence that met-Hb formation is enhanced by $2,3-\mathrm{DPG}$ $(26,32-34)$. This is irrelevant under normal conditions, since the met-Hb reducing capacity exceeds the demands some $150-$ fold. In hereditary NADH met-Hb reductase deficiency, however, an increased rate of met-Hb formation will result in an increase of the steady state met-Hb level in the red blood cell. 
Hemoglobin Function and Tissue Oxygenation. Oxidized hemoglobin does not take part in oxygen transport. In addition the left-shifted, more hyperbolic curve means restricted oxygen unloading from the remaining active hemoglobin. Both factors together interfere with oxygen supply to tissues, the more since cardiocirculatory adaptations are poor in methemoglobinemia (27). A quantitative estimate of the deficit of tissue oxygenation in methemoglobinemia may be derived from Figure 3. It shows the dependency of a fictive arterial venous oxygen difference $\left.(\mathrm{AVDO})_{2}\right)$ upon the degree of hemoglobin autoxidation at different levels of RBC 2,3-DPG, taking into account the quantitative and qualitative changes of hemoglobin function. As can be seen, these fictive $\mathrm{AVDO}_{2}$ values are considerably lowered in methemoglobinemia, particularly in the presence of fetal hemoglobin (Fig. 3b). Obviously, such impairment could interfere with growth and development of the brain and other organs.

Whether altered functional properties of hemoglobin are the predominant factor leading to brain damage in hereditary methemoglobinemia, cannot be derived from these figures which neglect the-although limited-in vivo adaptive mechanisms mentioned above. Recently Leroux et al. (22) demonstrated a generalized cytochrome $b_{5}$ reductase deficiency in non erythroid tissues in a patient with hereditary methemoglobinemia with mental retardation. In addition to reduced tissue oxygen supply such a defect may be the biochemical basis for irreversible cerebral dysfunction.

\section{CONCLUSION}

In solutions of hemoglobin, at $5 \mathrm{mM}$ concentration, tempera-

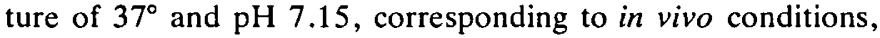
quantitative data on the oxygen transport function of blood in methemoglobinemia were determined for $\mathrm{HbA}$ and $\mathrm{HbF}$, respectively. The effects of 2,3-DPG were evaluated with respect to a possible influence on the oxidation pattern of $\alpha$ and non- $\alpha$ $(\beta$ and $\gamma$ ) chains within the hemoglobin tetramer, and to its influence on the $\mathrm{O}_{2}$-carrying characteristics of partially oxidized $\mathrm{HbA}$ and $\mathrm{HbF}$.

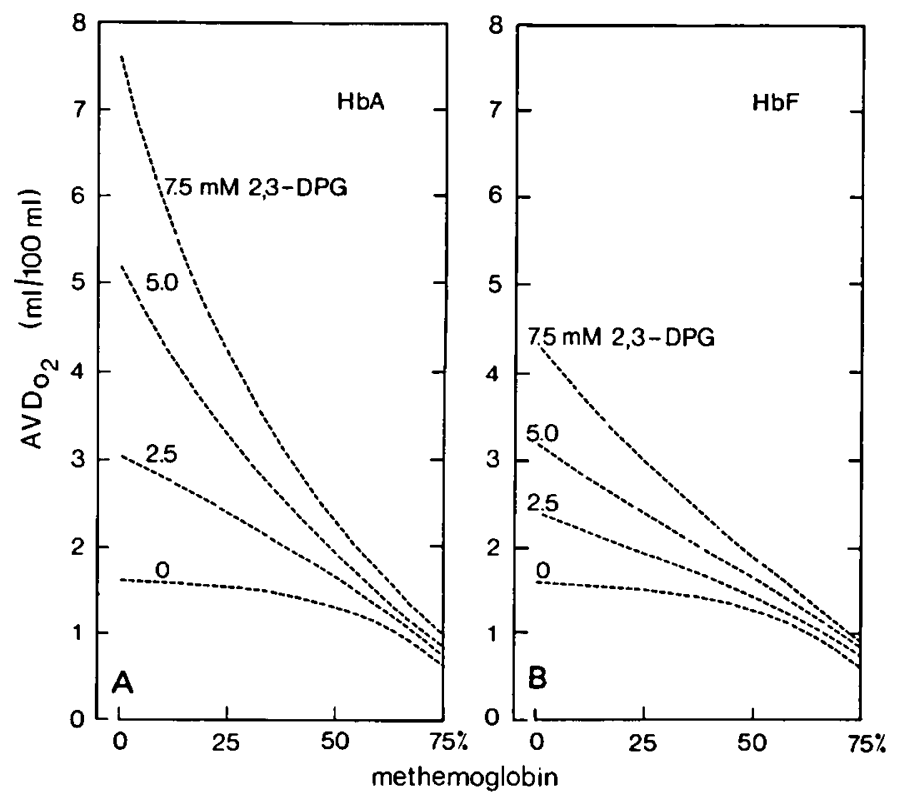

Fig. 3. Oxygen unloading from adult hemoglobin and from fetal hemoglobin at different 2,3-DPG concentrations depending upon the level of methemoglobin (abscissa). $\mathrm{AVDO}_{2}$ (ordinate) is the fictive arteriovenous $\mathrm{O}_{2}$ difference. Constants: total hemoglobin concentration $16 \mathrm{~g} / 100 \mathrm{ml}$ blood, red cell $\mathrm{pH} 7.15$, temperature $37^{\circ}$, arterial $\mathrm{PO}_{2} 80$ Torr, mixed venous $\mathrm{PO}_{2} 35$ Torr.
No evidence was obtained regarding a preferential autoxidation of $\alpha$ or non- $\alpha$ chains. $\mathrm{P}_{50}$, Hill's $n$, and 2,3-DPG reactivity of $\mathrm{HbA}$ and $\mathrm{HbF}$ decreased with increasting fractions of met$\mathrm{Hb}$. The Bohr effect remained unchanged. Evidently the reduced oxygen capacity in methemoglobinemia is of particular significance regarding the $\mathrm{O}_{2}$ unloading capacity of blood. In contrast to the adaptive $P_{50}$ increase in a comparable anemia, $P_{50}$ in methemoglobinemia is considerably lower; elevated $2,3-$ DPG levels do not favor blood oxygen release to the same extent as in anemia.

\section{REFERENCES AND NOTES}

1. Bartels, H., and Harms, H.: Sauerstoffdissoziationskurven des Blutes von Säugetieren (Mensch, Katze, Schwein, Rind, Schaf). Pflügers Arch. Ges. Physiol., 268: 334 (1959).

2. Bauer, $\mathrm{C}$.: Antagnostic influence of $\mathrm{CO}_{2}$ and 2,3-diphosphoglycerate on the Bohr effect of human haemoglobin. Life Sci., 8: 1041 (1969).

3. Bauer, C., Henry, Y., and Banerjee, R.: Binding of 2,3-diphosphoglycerate to haemoglobin valency hybrids. Nature, $241: 208$ (1973).

4. Bauer, C., Ludwig, I., and Ludwig, M.: Different effects of 2,3-diphosphoglycerate and adenosine triphosphate on the oxygen affinity of human adult and fetal hemoglobin. Life Sci., 7: 1339 (1968).

5. Benesch, R., and Benesch, R. E.: The effect of organic phosphates from the human erythrocyte on the allosteric properties of hemoglobin. Biochem. Biophys. Res. Commun., 26: 162 (1967).

6. Bunn, H. F., and Briehl, R. W.: The interaction of 2,3-diphosphoglycerate with various human hemoglobins. J. Clin. Invest., 49: 1088 (1970).

7. Bunn, F. H., and Jandl, J. H.: Exchange of heme among hemoglobin molecules. Proc. Nat. Acad. Sci. U. S. A., 56: 974 (1966).

8. Darling, R. C., and Roughton, F. J. W.: The effect of methemoglobin on the equilibrium between oxygen and hemoglobin. Amer. J. Physiol., 137: 56 (1942).

9. Edelstein, S. J., and Gibson, Q. H.: The effect of functional differences in the $\alpha$ and $\beta$ chains on the cooperativity of the oxidation-reduction reaction of hemoglobin. J. Biol. Chem., 250: 961 (1975).

10. Enoki, Y., Tokui, H., Tyuma, I., and Okuda, T.: Oxygen equilibria of partially oxidized hemoglobin. Resp. Physiol., 7; 300 (1969).

11. Evelyn, K. A., and Malloy, H. T.: Microdetermination of oxyhemoglobin, methemoglobin and sulfhemoglobin in a single sample of blood. J. Biol. Chem., 126: 655 (1938).

12. Forster, R. E.: The effect of dilution in saline on the oxygen affinity of human hemoglobin. In: $M$ Rørth and $P$. Astrup: Oxygen Affinity of Hemoglobin and Red Cell Acid Base Status, pp. 162-165 (Munksgaard, Copenhagen, 1972).

13. Itano, H. A., and Robinson, E.: Demonstration of intermediate forms of carbon monoxy and ferrihemoglobin by moving boundary electrophoresis. J. Amer. Chem. Soc., 78: 6415 (1956).

14. Jaffé, E. J., and Hsieh, H. S.: DPNH-methemoglobin reductase deficiency and hereditary methemoglobinemia. Semin. Hematol., 8: 417 (1971).

15. Jonxis, J. H. P., and Huisman, T. H. J.: A Laboratory Manual on Abnormal Hemoglobins, Ed. 2, (Blackwell Scientific Publications, Oxford, 1968).

16. Keitt, A. S., Smith, T. W., and Jandl, J. H.: Red-cell "pseudomosaicism" in congenital methemoglobinemia. N. Engl. J. Med., 275: 397 (1966).

17. Kiese, M.: Methemoglobinemia: A Comprehensive Treatise (CRP Press, Cleveland, Ohio, 1974).

18. Kleihauer, E., and Betke, K.: Elution procedure for demonstration of methaemoglobin in red cells of human blood smears. Nature, 199: 1196 (1963).

19. Kleihauer, E., and Betke, K.: Das Verhalten des Blutfarbstoffes innerhalb individueller menschlicher Erythrocyten bei experimenteller Oxidation und enzymatischer Reduktion. Acta Biol. Med. Germ., Suppl. III, 161 (1964).

20. Klingenmüller, $\mathbf{G}$, and Kiese, $M$.: Der Einflu $\beta$ partieller Hämiglobinbildung auf die Sauerstoffbindung des Blutfarbstoffes. Arch. Exp. Pathol. Pharmakol. 108: 195 (1949).

21. Kübler; W:; Kuhn, H., Mertens, H. M., and Seipel, L.: Familiärer Mangel an NADH-abhängiger Methämoglobin-Reduktase mit Glycerin-1-Phosphat-Dehydrogenase-Aktivität in den Erythrozyten. Klin. Wschr., 49: 1294 (1971).

22. Leroux, A., Junien, G., Kaplan, J. C., and Bamberger, J.: Generalized deficiency of cytochrome $b_{5}$ reductase in congenital methaemoglobinemia with mental retardation. Nature, 258: 619 (1975).

23. Mc Quarry, R. A., and Gibson, Q. H.: Functional heterogeneity of the $\alpha$ and $\beta$ chains in the oxidation-reduction reaction of human hemoglobin. $J$. Biol. Chem., 246: 517 (1971).

24: Maeda, T., Imai, K., and Tyuma, I.: Effects of 2,3-diphosphoglycerate on the oxygen equilibria of half-cyanmet hybrid hemoglobins. Biochemistry, I1: 3685 (1972).

25. Mansouri, A., and Winterhalter, K. H.: Non equivalence of chains in hemoglobin oxidation. Biochemistry, 12: 4946 (1973)

26. Mansouri, A., and Winterhalter, K. H.: Non equivalence of chains in hemoglobin oxidation: Effect of organic phosphates. Biochemistry, 13: 3311 (1974). 
27. Murray, J. F., and Escobar, E.: Circulatory effects of blood viscosity: Comparison of methemoglobinemia and anemia. J. Appl. Physiol., 25: 594 (1968).

28. Perutz, M. F.: Nature of haem-haem interaction. Nature, 237: 495 (1972).

29. Perutz, M. F., Pulsinelli, P. D., and Ramney, H. M.: Structure and subunit interaction of haemoglobin M Milwaukee. Nature, 237: 259 (1972).

30. Perutz, M. F., Ladner, J. E. Simon, S. R., and Ho, C.: Influence of globin structure on the state of heme. I. Human deoxyhemoglobin. Biochemistry, 13: 2163 (1974).

31. Tyuma, I., and Shimizu, K.: Different response to organic phosphates of human fetal and adult hemoglobins. Arch. Biochem. Biophys., 129: 404 (1969).

32. Versmold, H., Kohne, E., Riegel, K., Betke, K., and Kleihauer, E.: Oxygen carrying function of blood in hereditary methemoglobinemia: Ambivalent effects of 2,3-diphosphoglycerate. In: E. Gerlach, K. Moser, W. Wilmann, and E. Deutsch: Erythrocytes, Thrombocytes, Leukocytes, pp. 171-174 (Thieme, Stuttgart, 1973).

33. Versmold, H., Merkel, N., Riegel, K., and Betke, K.: Oxidation kinetics of human oxyhemoglobins: Influence of 2,3-diphosphoglycerate. II. Autoxidation and oxidation by nitrite. Abhandl, Acad. Wiss. DDR, 309 (1973).
34. Versmold, H., Ulmer, B., Riegel, K., and Betke, K.: Influence of 2,3diphosphoglycerate on the rate of oxidation of hemoglobin to methemoglobin. Klin. Wschr., 51: 93 (1973).

35. Woodson, R. D.: Red cell adaptation to cardiorespiratory disease. Clin. Hematol., 3: 627 (1974)

36. We wish to thank Dr. Christian Bauer for critical revision of the manuscript and Ms. Heidi Windthorst and Ms. Christine Luft for skillful technical assistance. The helpful suggestions and discussion of Dr. Enno Kleihauer and Dr. Erika Kohne are gratefully acknowledged.

37. This work was supported by Deutsche Forschungsgemeinschaft (SFB 51, Klinische Molekularbiologie und Biochemie).

38. Portions of this material were presented at the European Society for Pediatric Research, Seville, Spain, 1973 ([Abstr.] Pediat. Res., 8: 140, 1974), and as the M.D. thesis of K. Fürst at the University of Munich, Fachbereich Medizin.

39. Requests for reprints should be addressed to: H. T. Versmold, M.D. University of California, San Francisco, Cardiovascular Research Institute and Department of Pediatrics, San Francisco, CA 94143 (USA).

40. Received for publication March 15, 1977.

41. Accepted for publication June $28,1977$.

\section{Corrigendum}

In the article titled "Methylenetetrahydrofolate Reductase in Cultured Human Cells. I. Growth and Metabolic Studies" by David S. Rosenblatt and Richard W. Erbe in the November 1977 issue of Pediatric Research, formula 2, which appeared on p. 1137 , was published in incomplete form. It should have appeared as follows:

5-Methyl- $\mathrm{H}_{4}$ PteGlu + L-homocysteine 